\title{
ОСОБЛИВОСТІ ПСИХОЛОГІЧНОЇ КОРЕКЦІЇ ЕМОЦІЙНО-ВОЛЬОВОЇ СФЕРИ ДІТЕЙ МОЛОДШОГО ШКІЛЬНОГО ВІКУ 3 ОСОБЛИВИМИ ОСВІТНІМИ ПОТРЕБАМИ
}

У статті проаналізовані особливості проведення корекиійних занять з дітьми молодшого шкільного віку, які мають особливі освітні потреби. Висвітлено переваги та недоліки корекиійних програм та специфіку підбору вправ для такої категорії дітей. Визначено, щуо порушення емочійно-вольової сфери - одна з найбільш складних та найменш досліджених проблем у психології. Обтрунтовано, щзо психокорекційна робота базується не на особливостях навчального закладу, а на індивідуальних особливостях дітей, які незалежно від системи освіти мають отримувати весь комплекс необхідних корекиійнорозвивальних заходів, спрямованих на ї̈ адаптацію у соціальному середовищі.

Ключові слова: молодший шкільний вік, корекційна робота, особливі освітні потреби.

В статье проанализированы особенности проведения коррекиионных занятий с детьми младшего школьного возраста, имеющие особые образовательные потребности. Освещены преимущества и недостатки коррекционных программ и специфику подбора упражнений для такой категории детей. Определено, что нарушения эмочиионально-волевой сферы - одна из самых сложных и наименее исследованных проблем в психологии. Обосновано, что психокоррекционная работа базируется не на особенностях учебного заведения, а на индивидуальных особенностях детей, независимо от системы образования должны получать весь комплекс необходимых коррекционно-развивающих мероприятий, направленных на ее адаптаџию в сочиальной среде.

Ключевые слова: младший икольный возраст, коррекиионная работа, особые образовательные потребности.

Постановка проблеми. На сьогодні питання організації ефективної корекційної роботи 3 дітьми молодшого шкільного віку є гострим та актуальним. Особлива увага приділяється пошуку корекційних вправ того чи іншого напрямку, які б були дієвими в конкретній групі дітей. Проте, до сьогодні не існує універсальних програм, які б давали значні результати занять з дітьми, що мають особливі освітні потреби. Організація корекційних занять є одним 3 важливих питань, як для психологів, так і для освітян. Правильне та своєчасне включення дитини в подібну роботу дозволить їй розвинути певні особистісні структури, розкрити компенсаторні можливості та змінити їі уявлення як про особистість. Саме корекційні заняття допоможуть дітям, що мають особливі освітні потреби повірити в себе та знайти своє місце в соціальному середовищі, навчитися встановлювати здорові соціальні контакти, а також адекватно оцінювати свої можливості та недоліки. Тому, саме організація корекційних заняття для осіб, які цього потребують є одним 3 важливих завдань сучасного українського суспільства.

Аналіз останніх досліджень i публікацій. Корекційно-розвитковій роботі присвячено низку досліджень у різних галузях дефектології та психології. Дослідженнями у цій сфері займалися такі вчені, як В.І.Бондар, Н.Ф.Засенко, І.Г.Сременко, С.П.Миронова, В.М.Синьов, Є.П.Синьова, С.В.Федоренко, Л.І.Фомічова, О.П.Хохліна, А.Г.Шевцов, М.К.Шеремет та ін. Серед вітчизняних дослідників особливу увагу цим питанням приділяли А.І.Захаров, М.І.Буянов, А.В.Запорожець, Л.С.Виготський та ін.

Основні принципи, методи і можливі форми організації корекційної допомоги дітям, що зазнають емоційне неблагополуччя, виділені в роботах таких вітчизняних і зарубіжних дослідників, як С. А. Беличева, Г. В. Бурменской, I. П. Воропаєва, I. В. Дубровіна, О.А. Карабанова, . Ю. Левченко, А. К. Маркова, С.А. Медведєва, О. С. Нікольська, Г. І. Репринцева, Г.А. Лендрет, К. Роджерс, К. Рудестам, В. Сатир, К. Фопель, Г. Еберлейн та 
ін. У в педагогіці проблемі емоційного розвитку та виховання дітей приділялося менше уваги. Тим не менше, як указує Л. В. Крюкова на основі узагальнення низки досліджень, питання емоційного розвитку отримали відображення у пошуках способів оптимізації навчально-пізнавальної та суспільно-корисної діяльності таких педагогів, як Ю.К. Бабанський, А.В. Занков, А.Д. Кошелева, Н.Г. Морозова, Я.З. Неверович, 3. І. Равкин, К. Д. Радіна, Г.І. Щукіна, М. І. Юр'єва та ін. [2, с. 102].

Порушення емоційно-вольової сфери - одна 3 найбільш складних та найменш досліджених проблем у психології. Так, С. Г. Шевченко, узагальнюючи наукові підходи до організації цілісної системи корекційно-розвивального навчання дітей із затримкою психічного розвитку різного генезу, а також дітей, що мають парціальні порушення, що створюють специфічні труднощі в засвоєнні навчальних програм, в адаптації до вимог школи, вказує на ті, які набули найбільшого розповсюдження: 1) це діти функціональною несформованістю префорнтальних (лобних) відділів головного мозку та дефіцитарністю підкіркових утворень (базальних ядер) (за нейропсихологічною класифікацією А.В. Семенович); 2) діти з астенічними, станами і конфліктними переживаннями та діти 3 психопатоподібними формами поведінки і з початковими проявами психічних захворювань (за класифікацією Г.Н. Коберника, В.М. Синьова); 3) діти зі спотвореним (дисгармонійним розвитком) (за класифікацією Є.А. Лапшина, Б.П. Пузанова); 4) діти 3 викривленим та дисгармонійним розвитком (за класифікацією В.В. Лебединського) [7, с. 217].

У той же час значно менше вивчені внутрішні чинники, які впливають на психічне здоров'я дітей та умови становлення здорової психіки. Одним з таких внутрішніх факторів $\epsilon$ емоційна сфера як складно організована система регуляції поведінки дитини. Стійкість емоційної сфери дитини напряму залежить від якості емоційного спілкування з батьками, і в першу чергу 3 матір'ю. Дефіцит батьківської любові призводить до уповільнення формування самосвідомості дитини, а в подальшому - до закріплення в соціальному досвіді агресивного, ворожого ставлення до світу. Все це призводить до виникнення у дітей різного роду емоційних порушень. Спектр емоційних порушень у дитячому і підлітковому віці надзвичайно великий. Це можуть бути важкі невротичні конфлікти, неврозоподібні стани у дитини внаслідок органічного ураження центральної нервової системи, преневротичні стани, акцентуації характеру, крім того достатньо розповсюджені страхи, тривожність, агресивність тощо. У психологічній літературі емоційні порушення у дітей трактуються як негативний стан, що виникає на тлі важко вирішуваних особистісних конфліктів [ 1, с. 191]. Проте, незалежно від класифікації та спектру порушень, вони неодмінно потребують комплексного та компетентного підходу до проведення та організації корекційної роботи. Саме така робота здійснюється у межах навчального процесу, тому досить важливим є розуміння специфіки навчання дітей з особливими освітніми потребами.

У початковій школі передбачено чотири варіанти навчання для дітей з особливими потребами з урахуванням структури і складності психофізичного порушення і можливостей учня: I варіант - загальноосвітня підготовка; II варіант - корекційно-розвивальне навчання (для подолання труднощів у навчанні, пов'язаних із соціальною депривацією, педагогічною занедбаністю, затримкою психічного розвитку); передбачає поглиблену роботу з корекції психічних функцій, пізнавальної діяльності, навичок спілкування, а також з розвитку вмінь і навичок у процесі трудового навчання спроможності і здібностей дітей; III варіант компенсаторно-адаптаційне навчання (для дітей із вираженими інтелектуальними порушеннями та комбінованими вадами розвитку); IV варіант - абілітаційне навчання (для дітей зі складними комплексними відхиленнями в розвитку) [6, с. 325].

Корекційна робота - це діяльність, спрямована на поліпшення процесів розвитку i соціалізації дитини, послаблення або подолання психофізичних вад учнів у процесі навчання і виховання з метою максимально можливого розвитку їхньої особистості та підготовки до самостійного життя [5, с. 28]. Проте, існує у вжитку термін «корекційно-розвивальна робота», його на разі закріплено у документах про спеціальну та інклюзивну освіту. Корекційна робота базується не на особливостях навчального закладу, а на індивідуальних особливостях дітей, які в ньому навчаються. Тому досить важливо, щоб дитина не залежно 
від системи освіти отримувала весь комплекс необхідних корекційно-розвивальних заходів, які спрямовані на її адаптацію у соціальному середовищі.

Також, варто звернути увагу на основні корекційні прийоми, які можна використовувати при роботі з дітьми, які мають порушення емоційно-вольової сери, а саме основні серед них наступні:

- повторюйте вказівки. Записуйте їх. Промовляйте їх. Людям з гіперактивності потрібно чути одне і те ж більше одного разу;

- підтримуйте постійний візуальний контакт. Ви можете одним поглядом «повернути» дитину «до реальності». Робіть це частіше. Погляд може пробудити дитину від мрій, дозволити поставити запитання або заспокоїти. Посадіть дитину поблизу від себе. Це допоможе зберігати увагу;

- установіть кордони, це не покарання: межі стримують і заспокоюють. Робіть це послідовно, впевнено і просто. Не вступайте у складні силові дискусії про справедливість. Такі дискусії та суперечки тільки відволікають, діти все одно вас «не почують»;

- стежте за прогресом. Постійний зворотний зв'язок приносить дітям величезну користь. Він дозволяє знати, чого від них очікують і чи досягли вони поставлених цілей, а також значно заохочує і підтримує;

- розбивайте довгі завдання на коротші. Це один з найважливіших методів роботи вчителя 3 дітьми з гіперактивністю. Коли завдання розбивають на складові частини, які можна виконати окремо, кожна частина здається досить маленькою, щоб впоратися з нею і виконати іiі. Це дозволяє дитині відкласти в бік відчуття перевантаження і нездатності виконати завдання. Зазвичай такі діти здатні на більше, ніж їм здається;

- на другому етапі корекційної роботи поступово формуйте здатність стримувати імпульсивні реакції, не відволікатись, розвивати цілеспрямованість діяльності. 3 цією метою можна поступово збільшувати інтервал часу між стимулом та реакцією;

- задавайте питання, які спонукають до саморозуміння та рефлексії. «Ти знаєш, що ти тільки що зробив?», «Як ти вважаєш, чому ця дівчинка засмутилася, коли ти таке сказав?», «Давай подумаємо, що тут потрібно зробити», «Так на чому ми зупинилися?»;

- звертайте увагу на взаємне спілкування дітей. Цим дітям необхідно відчуття зайнятості та залученості. Доки вони зайняті, у них є мотивація, а тому менше шансів, що вони «відключаться». Покладіть на дитину відповідальність, коли це можливо [3, с. 57-60].

Формулювання цілей статті. На основі попередньо проведеної нами діагностики сформованості емоційно-вольової сфери дітей молодшого шкільного віку 3 особливими освітніми потребами, подальше завдання полягає у розробці та проведенні комплексної корекційної роботи з дітьми першого та четвертого класів.

Виклад основного матеріалу дослідження. Вибірка дітей складалась 319 учнів спеціалізованого навчального закладу, які мають порушення мовлення. До дослідження були залучені учні 1 та 4 класу, які склали дві досліджувані групи. Корекційні заняття проводилися в першій та другій групі відповідно. Тривалість заняття коливається в межах 35-45 хвилин. Заняття включають психогімнастичні вправи, вправи на розвиток та корекцію емоцій та волі та арт-терапевтичні вправи.

Під час проведення першого корекційного заняття у першому класі, було використано заняття розроблене Г. М. Нижник, практичним психологом дошкільного навчального закладу № 2 «Дударик» Коломийської міської ради. Програма заняття складалася 3 наступних вправ: вправи «Знайомство», «Я вмію»; казка «Секрет працьовитості» (М. Скребцової); гра «Маленькі помічники»; вправи «За що мене любить мама?», «Релаксація». Проте, проведене заняття виявило певні складнощі у виконанні підібраних завдань. Дітям такого віку досить складно сприймати матеріал на слух, а також за допомогою жестів зобразити певні дії. Також певні труднощі викликала вправа «Я вмію», діти не змогли диференціювати власні вміння та запропоновані їм висловлювання. Тому, наступним етапом було спрощення завдань та корегування подальших занять. 
Друге заняття у цьому ж класі складалось 3 наступних вправ: «Будь-ласка», «Змінюємо обличчя», «Вгадай емоцію», «Будівники», «Тренуємо емоцію», «Розвиток мімічних рухів», «Прощання-побажання». Завдання були дещо спрощені, проте і ці вправи дітям виконати було тяжко. Досить тяжко давались вправи на зображення емоцій а також їх відгадування, оскільки як показало виконання вправи не всі присутні знали базові емоції. Проте, це заняття мало і свої плюси, а саме вдалося розвинути мімічні рухи та від тренувати деякі емоції, проте це вдалося за рахунок ігрової невимушеної форми.

Третє, проведене нами заняття, базувалось на досить не складних формах роботи. Саме такі форми мали ігрову форму, проте були направлені на розвиток необхідної сфери. Воно базувалось на вправах 3 м'ячем, що спрямовані на розвиток дрібної моторики дітей, а також одночасне включення емоційної та вольової сфери учнів. Вправа «Передай м'яч збоку» дозволила зосередити більшу увагу на вольовому компоненті особистості дитини, у виконанні не вимагала певних вмінь та особливих знань чи навичок. Тому, саме 3 нею труднощів помічено не було. Також, було використано завдання, яке полягало у з'єднанні малюнку та його розфарбовуванні. Перший компонент вправи дозволив розвинути вольові якості дитини, а другий - емоційну сферу. Саме вона частково викликала перешкоди у виконанні, особливо перша частина завдання. Тому, з метою підвищення продуктивності корекційних заняття з дітей першого класу було сформовано дві підгрупи. Подальші заняття будуть проводитися в першій та другій групі учнів відповідно.

Під час проведення корекційних занять у четвертому класі було використано елементи програми культури життєвого самовизначення у поєднанні 3 вправами інших корекційних програм. Перше корекційне заняття складалося з наступних завдань: Вправи «Моє ім'я», «Що я люблю», «Малюю автопортрет», «Я вмію», «Тренуємо емоції»; домашнє завдання. Врахувавши, недоліки попередніх занять у іншій групі це заняття було сформовано більше на знайомство 3 дітьми та налагодження контакту, ніж на розвиток та корекцію емоційно-вольової сфери. Звертаючи увагу на вікові особливості цієї групи, помітних труднощів під час цієї зустрічі помічено не було. Друге ж заняття було більше спрямоване на мету нашого дослідження та побудоване на наступних вправах: «Місток дружби», «Емоція по колу», «Броунівський рух», «Крокодил», «Мої емоції», «Дерево». Звертаючи увагу на кращу обізнаність дітей в сфері емоцій та їх старший вік проводити заняття було досить легко, діти швидко включались в заняття, розуміли зміст інструкцій, використовували свої шкільні знання, що вплинуло на продуктивність цієї зустрічі. Скелет третього корекційного заняття утворили такі підібрані нами вправи: «Комарі», «Будівники», «Чарівні острови», «Мімічна гімнастика», «Зобрази на обличчі», «Вгадай емоцію», «Зафарбуй емоції». Під час проведення було зафіксовано поглиблення учнівських знань про емоції людини, відтренувати мімічну сторону емоцій, змінити загальну атмосферу в групі на більш позитивну та невимушену, а також краще ознайомлення дітей з основними проявами базових емоцій людини. Складнощі під час цієї роботи не виникали, учні активно включалися в роботу та охоче виконували поставлені завдання.

Четверте ж корекційне заняття було сформовано за допомогою наступних вправ: «Нетрадиційне привітання», «Зобрази свою іграшку», «Кричалки - шепотілки - мовчалки», «Малюємо настрій», «Золоті рибки», «Квіти». У цій зустрічі завдання було спрямовано як на емоційну, так і на вольову сферу дитини, а також на іiі особистісні якості. Вправа «Малюємо настрій» носить як ар-терапевтичне спрямування, так і спрямована на будування асоціативного зв'язку між кольором та певним емоційним станом людини. Інші ж вправи задіювали як і вольові якості дитини, так і на розвиток пантоміміки та жестів. А також спрямовані на покращення особистісного та групового емоційного фону.

Висновки 3 даного дослідження і перспективи подальших розвідок. У дослідженні визначено напрямки організації корекційних занять 3 дітьми молодшого шкільного віку, спрямованих на розвиток емоційно-вольової сфери. В учнів 3 особливими освітніми потребами спостерігаються певні труднощі у володінні власними емоціями та включенні вольової регуляції діяльності. Також, виявлено відсутність достатніх знань про емоції людини, а також способи їх вираження. 
Перспективою подальшої роботи буде формування адекватних знань учнів про емоційно-вольову сферу особистості, розвиток вмінь контролю власних емоційних проявів та вольової сфери та формування орієнтовних корекційних програм для учнів першого та четвертого класу, що мають особливі освітні потреби.

\section{Список використаних джерел}

1. Кротенко В. І. Психологічна корекція емоційних порушень у дітей молодшого шкільного віку засобами арт-терапії (у проективному ключі) / В. І.Кротенко, К. С. Стрілець // Науковий часопис НПУ імені М. П. Драгоманова. Серія 19 : Корекційна педагогіка та спеціальна психологія : зб. наук. пр. - Київ : НПУ імені М. П. Драгоманова, 2015. - Вип. 29. - С. 190-196.

2. Крюкова Л.В.Корекція емоційної сфери молодшого школяра як основного чинника адаптації у соціумі / Л. В. Крюкова // Психологія: реальність і перспективи : зб. наук. пр. Рівнен. держ. гуманіт. ун-ту. - Рівне, 2013. - Вип. 2. - С. 102-105.

3. Миронова С. П. Засоби корекційної роботи у навчально-виховному процесі спеціальних та інклюзивних закладів / С. П. Миронова // Науковий часопис НПУ імені М. П. Драгоманова. Серія 19 : Корекційна педагогіка та спеціальна психологія : зб. наук. пр. - Київ : НПУ імені М. П. Драгоманова, 2014. - Вип. 26. - С. 149-152.

4. Миронова С. П. Олігофренопедагогіка : компакт. навч. курс : навч. посіб. / С. П. Миронова. - Кам'янець-Подільський : Кам'янець-Поділ. держ. ун-т, 2008. - 204 с.

5. Савчук Л. І. Корекційне навчання дітей із зпр в умовах загальноосвітньої школи / Л. І. Савчук // Актуальні проблеми навчання та виховання людей з особливими потребами : зб. наук. пр. / Відкр. міжнар. ун-т розвитку людини "Україна", Ін-т вищ. освіти НАПН України, Ін-т спец. педагогіки НАПН України. - Київ : Ун-т "Україна". - 2004. - Вип. 1 (3). C. 324-330.

6. Терещук А. Д. Психологічна допомога дітям з порушеннями емоційної сфери / А. Д. Терещук // Збірник наукових праць Ін-ту психології ім. Г. С. Костюка НАПН України. Проблеми загальної та педагогічної психології. - 2012. - Т. 24, ч. 5. - С. 217-229.

7. Шевченко С. Г. Диагностика и коррекция задержки психического развития у детей : пособ. для учителей и специалистов коррекционно-развивающего обучения / С. Г. Шевченко, Н. Н. Малофеев, А. О. Дробинская и др. ; под ред. С. Г. Шевченко. - М. : АРКТИ, 2001. $224 \mathrm{c}$.

\section{References}

1. Krotenko V. I. Psihologichna korekciya emocijnih porushen' u ditej molodshogo shkil'nogo viku zasobami art-terapiï (u proektivnomu klyuchi) / V. I. Krotenko, K. S. Strilec' // Naukovij chasopis NPU imeni M. P. Dragomanova. Seriya 19 : Korekcijna pedagogika ta special'na psihologiya : zb. nauk. pr. - Kiïv : NPU imeni M. P. Dragomanova, 2015. - Vip. 29. - S. 190-196.

2. Kriukova L. V. Korektsiia emotsiinoi sfery molodshoho shkoliara yak osnovnoho chynnyka adaptatsii u sotsiumi / L. V. Kriukova // Psykholohiia: realnist i perspektyvy : zb. nauk. pr. Rivnen. derzh. humanit. un-tu. - Rivne. - 2013. - Vyp. 2. - S. 102-105.

3. Mironova S. P. Zasobi korekcijnoï roboti u navchal'no-vihovnomu procesi special'nih ta inklyuzivnih zakladiv / S. P. Mironova // Naukovij chasopis NPU imeni M. P. Dragomanova. Seriya 19 : Korekcijna pedagogika ta special'na psihologiya : zb. nauk. pr. - Kyiv : NPU imeni M. P. Dragomanova, 2014. - Vip. 26. - S. 149-152.

4. Mironova S. P. Oligofrenopedagogika : kompakt. navch. kurs : navch. posib. / S. P. Mironova. - Kam'yanec'-Podil's'kij : Kam‘yanec'-Podil. derzh. un-t, 2008 - 204 s.

5. Savchuk L. I. Korekcijne navchannya ditej iz zpr v umovah zagal'noosvitn'oï shkoli / L. I. Savchuk // Aktual'ni problemi navchannya ta vihovannya lyudej z osoblivimi potrebami : zb. nauk. pr. / Vidkr. mizhnar. un-t rozv. lyudini "Ukraïna", In-t vishch. osviti NAPN Ukraïni, In-t spec. pedagogiku NAPN Ukraïni. - Kyiv : Un-t "Ukraïna". - 2004. - Vip. 1 (3). - S. 324-330. 
6. Tereshchuk A. D. Psihologichna dopomoga dityam z porushennyami emocijnoï sferi / A. D. Tereshchuk // Zbirnik naukovih prac' In-tu psihologiï im. G. S. Kostyuka NAPN Ukraïni. Problemi zagal'noï ta pedagogichnoï psihologiï. - 2012. - T. 24, ch. 5. - S. 217-229.

7. Shevchenko S. G. Diagnostika i korrekcija zaderzhki psihicheskogo razvitija u detej : posob. dlja uchitelej i specialistov korrekcionno-razvivajushhego obuchenija / S. G. Shevchenko, N. N. Malofeev, A. O. Drobinskaja i dr. ; pod red. S. G. Shevchenko. - M. : ARKTI, 2001. - 224 s.

M. A. Kots, T. M. Yatchuk. FEATURES OF PSYCHOLOGICAL CORRECTION OF THE EMOTIONAL-VOLITIONAL SPHERE OF CHILDREN OF PRIMARY SCHOOL AGE WITH SPECIAL EDUCATIONAL NEEDS.

The article analyzes the peculiarities of conducting remedial classes with children of primary school age with special educational needs. The advantages and disadvantages of corrective programs and the specifics of the selection of exercises for this category of children. It is determined that violations of the emotional and volitional sphere is one of the most difficult and least researched problems in psychology.

It is stated that the organization of remedial classes is one of the important issues for psychologists and teachers. The correct and timely inclusion of the child in such work will allow her to develop certain personal structures, to open compensatory opportunities and change her idea as a person. It is correction classes that will help children with special educational needs to believe in themselves and find their place in the social environment, learn how to establish healthy social contacts, and adequately assess their opportunities and shortcomings.

It is revealed that students with special educational needs have certain difficulties in owning their own emotions and including the volitional regulation of activity. Also, there is a lack of sufficient knowledge about human emotions, as well as ways to Express them.

It is proved that psychological intervention work is based not on the characteristics of the institution and on the individual characteristics of the children who regardless of the system of education must obtain all necessary remedial and developmental measures aimed at its adaptation to the social environment.

Keywords: primary school age, correctional work, special educational needs.

УДК 316.614:316.334.55/.5

\section{ПСИХОЛОГІЧНІ ВІДМІННОСТІ В САМОРЕАЛІЗАЦІї ПІДЛІТКІВ МІСТА ТА СЕЛА}

У статті здійснено аналіз процесу самореалізаџї особистості. Визначено, щуо розвиток наукового розуміння изього феномену належить представникам екзистенційногуманістичного напряму. Констатовано, щзо з підліткового віку особистість психологічно готова до повноиінної самореалізаиії себе в суспільстві.

Емпірично встановлено, що сочіалізачія дітей в місті, а ніж у селі, більшою мірою сприяє їх самореалізації в суспільстві.

Ключові слова: самореалізаџія, гуманістична школа, підлітковий вік, сочіалізація.

В статье осуществлен анализ процесса самореализации личности. Определено, что развитие научного понимания этого феномена принадлежит представителям экзистенциально-гуманистического направления. Констатировано, что с подросткового возраста личность психологически готова к полноценной самореализации себя в обществе.

Эмпирически установлено, что социализация детей в городе в большей степени, нежели в деревне, способствует их самореализачии в обществе.

Ключевые слова: самореализация, гуманистическая школа, подростковый возраст, сочииализачия.

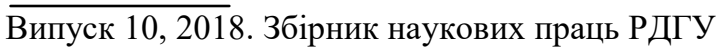

